\title{
Peripheral Odontogenic Fibroma
}

National Cancer Institute

\section{Source}

National Cancer Institute. Peripheral Odontogenic Fibroma. NCI Thesaurus. Code C4315.

A rare, benign, extraosseous neoplasm arising from tooth-forming tissues. It usually presents as a slow growing exophytic mass in the gingiva. It is characterized by the presence of odontogenic epithelium which is embedded in a fibrous stroma. 